\title{
The Influence of Translators' Cultural Identity on the Translation of Lunyu
}

\author{
Qun $\mathrm{Li}^{1}$ \\ ${ }^{1}$ Department of Foreign Language Teaching, Taishan University, Taian City, Shandong Province, China \\ Correspondence: Qun Li, Department of Foreign Language Teaching, Taishan University, Taian City, Shandong \\ Province, China. E-mail: liqunmiss@163.com
}

Received: August 29, 2014

Accepted: September 17, 2014 Online Published: October 1, 2014

doi:10.5539/ijel.v4n5p130

URL: http://dx.doi.org/10.5539/ijel.v4n5p130

\begin{abstract}
As a representative of the Chinese classics, Lunyu was researched by numerous scholars. There are a lot of factors that influence the translation of Lunyu. In this paper, through analysis of their translated versions and their cultural identity, the author explored how a translator's cultural identity influences his translation. In conclusion, it leads to a final conclusion through the discussion: the translators' identity determines the translating purposes, and translating purposes determine selection of translating strategies; translators' cultural identity influences their translation of cultural messages.
\end{abstract}

Keywords: translators' identity, culture, translation of Lunyu

\section{Introduction}

As a representative of Chinese classics, Lunyu was researched by numerous scholars. It is the foundation of the moral, social, and political life of the Chinese people; hence the translation of Lunyu is of great significance in the communication of eastern and western cultures. There are a large number of English versions of Lunyu. There are a lot of factors that influence the translation of Lunyu. This paper intends to study the connection between translators' cultural identity and their translations.

Translation, as a mean of communication between different languages and societies, is inevitably undertaken in a cultural environment. Translator, as the key performer of the translation process, has a significant influence on his translation. He or she is a member of a certain nation; he or she lives in a particular country in a particular period of time; he or she is a product of a specific culture, and all the factors such as race, gender, class, education, ideological features and so on have an impact on the translation itself.

Three translators mentioned in this paper all enjoy a reputation of high quality, and they have different cultural identities. In this paper, through comparative analysis of their translated versions and their cultural identity, the author explored how a translator's cultural identity influences his translation.

\section{Identity and Translation}

\subsection{The Definition of Cultural Identity}

Identity is a key term in the recent cultural studies. Before discussing the cultural identity, it is necessary to make clear what culture is. There are many different cultures in the world, and divided by various standards, we have western and eastern culture, by ideology; Chinese culture, American culture, Indian culture, etc, by nation; Christian culture, Muslim culture, and Buddhism culture, by religion. As much as it has been used, however, it is not easy to give a precise definition for the term "culture". There many definitions of culture.

Bates and Plog put it: Culture is a system of shared beliefs, values, customs, behaviors, and artifacts that the members of a society use to cope with their world and with one another, and that are transmitted from generation to generation through learning. This definition includes not only patterns of behavior but also patterns of thought (shared meanings that the members of a society attach to various phenomena, natural and intellectual, including religion and ideologies), artifacts (tools, pottery, houses, machines, works of art), and he culturally transmitted skills and techniques used to make the artifacts (Bates \& Plog, 1990, p. 28).

This is a commonly accepted definition. It includes major aspects of culture. And we should also make clear what identity is. 
Stuart Hall put it: Identity is to define oneself against what one is not: to be English is to know yourself in relation to the French, and the hot-blooded Mediterranean, and the passionate traumatized Russian soul. You go round the entire globe: when you know what everybody else is, then you are what they are not (Hamers \& Blanc, 1989, p.116).

The essential concept about identity is the recognition of some characters or features that function as the yardstick of belongingness or exclusion, that "define" a person or a group. Therefore, identity is always involved in comparing with "the other".

When one's personal identity integrates with the culture he's from or the cultures he experiences, one's cultural identity is under formation. As Hamers and Blanc succinctly put it "the integration of the complex configuration that is culture into the individual's personality constitutes his cultural identity." (Legge, 1971, p.19).

It is obvious that identity is in the dynamic process of constructing. The construction of the translator's cultural identity is mostly based on his or her cultural ideological, tropism of value, and culture blood, concerned with personal and collective attitudes, from native, national and global perspectives. Relationship between Cultural Identity and Translation

\subsection{Relationship between Cultural Identity and Translation}

Due to cultural differences, the audience which translation is intended for usually has different expectations and understanding of the texts from the audience who read the originals, and the status of the texts is usually different in source and target cultures. In current translation studies, the signification of culture has drawn more and more attention. Culture has become an undetectable part of translation studies. Translation is not just a practice of conversion of languages, but an exchange between cultures.

A translator doesn't come out of nowhere, he or she has a primary identity: he or she is a member of a certain nation; he or she lives in a particular country in a particular period of time; he or she has certain religious belief, and all the factors such as race, gender, class, education, ideological features have an impact on the translation. They all leave a detectable trace in the translation work. Different historical time has different norms and standards on translation, which is greatly determined by target readers and the purpose of translation, therefore, translators, in order to produce satisfactory translations suiting his time and culture, would adopt certain translating strategies. Besides, the translator's native culture and nation affect his choices too. Therefore, the study of the translator will reveal to us what's usually hidden but secretly influences the translation.

\section{Culture Identity of Its Translators}

Like most great works in the world, Lunyu has been constantly translated and introduced to many cultures. Since the appearance of the first English translation of Lunyu in 1809 by Joshua Marshman, there are over 30 English translated versions over the years. Let's discuss three representatives of them.

\subsection{British Missionary and Sinologist—James Legge}

The first widely known and influential English translation of Lunyu was done by the famous British missionary and sinologist James Legge. In 1861, he published Confucian Analects, The Great Learning and The doctrine of the Mean, included in his translation series of The Chinese Classics. Legg's translation remains one of the most important and influential English translations of Lunyu even today.

The identity of James Legge was a complicated mix. He was a sincere Christian missionary, a celebrated sinologist, a prolific translator and a respectable teacher. He grew up and was educated in Britain, lived in China for 30 years, a native English speaker with a high proficiency in both modem and ancient Chinese, studied and translated a series of the most important Chinese classics into English. The most noticeable feature of Legge's version is the fidelity to the original. He wrote in his preface that "He thought indeed at one time of recasting the whole version in a terser and more pretentious style. He determined, however, on reflection to let it stand as it first occurred to him, his object having always been faithfulness to the original Chinese rather than grace of composition. Not that he is indifferent to the value of an elegant and idiomatic Rendering in the language of the translation, and he hopes that he was able to combine in a considerable degree correctness of interpretation and acceptableness of style." (Nord, 2001, p. 89) In addition to the texts and translations, many detailed notes in his version are offered to the reader, which is very helpful for better understanding. But over-faithfulness to the original leads to some word-for-word translations. In addition, due to too much literal translation, his version reads less elegant. His style may be sumarized in three words "faithful, tedious, and rigid".

\subsection{British Sinologist-Arthur Waley}

Arthur Waley served as a research fellow in the Oriental Section of the British Museum for a long time. Due to 
his immense interest in ancient Chinese civilization, he decided to research Chinese culture on his own. He has been referred as an authority in Confucius and Li Bai research by The British Cyclopedia. Waley has his own opinion on how to translate classics. As for the Analects of Confucius, he thought the former versions depended too much on Zhu Xi's annotations. To Waley, Zhu $\mathrm{Xi}$ is someone like a missionary, who put Confucius in a position of God or a sage. But this just distorted the meanings of Confucius. Therefore Waley wanted to make his own version. His version is regarded as faithful and fluent with extensive footnotes and explanations of some key concepts. From the layout of his version, it is obvious that his version is intended for native English readers and the people interested in academic research.

\subsection{Chinese Scholar and Philosopher-D.C Lau}

D.C. Lau is a contemporary Chinese sinologist. His Sinological career spans decades and extends across disciplines. He was born in Hong Kong. He majored in Chinese at Hong Kong University and, in 1946, went to Glasgow, where he read philosophy. In 1949, having finished the courses of master he went to teach at London University. In 1978 he returned to Hong Kong. The life experience of D.C. Lau indicates that his cultural identity is somewhat a hybrided one. As he grew up and was educated in Hong Kong in his early years, the Chinese culture and tradition was rooted in his primary cultural identity. However, different from many other Chinese scholars, he received a systematic education of philosophy in a top western university, and spent three decades teaching and researching there. This experience is definitely non-negligible in the construction of his cultural identity. His translation is simple and easy to understand due to the use of colloquial style and simple sentences. His intended readers are those who know no Chinese, and it is more suitable to western readers.

\section{The Culture Identity of Translators Determine Translating Purposes}

Translating purpose is essential in a translator's choice of translating strategies and his adoption of translation criteria. Every text is "produced for a given purpose and should serve this purpose." (Nida, 1969, p. 176) Whether consciously or not, before translating, there is an intention or purpose in a translator's mind, such as what function the translation will serve, who are the intended readers and so on. The Renditions of Lunyu are no exception. All the translators have their own plans which result in many differences.

James Legge and D.C. Lau, due to their distinctive cultural identity, had different purposes of translating Lunyu. James Legge's translation of Lunyu and other Chinese classics was predetermined by his identity as a Christian missionary. The purpose of studying the Chinese mind was to introduce Christian to the Chinese people. Arthur Waley's version is intended for native English readers and the people interested in academic research. D.C. Lau, on the other hand, as a Chinese scholar, translated Lunyu to introduce Chinese classics to the west. The different purposes as well as social background and times of their lives influenced their translation. In the following, the I will illustrate this point from aspects: the influence of their different target readers and their respective application of translation strategies.

\subsection{The Translating Purposes Determine Target Readers}

Target reader is a significant part of the translation considerations. Every translator has specific target readers in mind before he starts translating, in fact, before he picks out the specific text to translate. Nida reminded us the status of the readers in his The Theory and Practice in Translation: Even the old question "Is this a correct translation?" must be answered in terms of another question, namely: for whom? Correctness must be determined by the extent to which the average reader for which a translation is intended will be likely to understand it correctly (Ride, 1960, p.58).

James Legge studied Confucianism because it would help him fulfill his duties as a Christian missionary, and the translation was intended to help more missionaries accomplish their missions. The more notes he gave, the better he can help them understand and find the gateway for the Chinese. Arthur Waley's version is intended for native English readers and the people interested in academic research. His version is regarded as faithful and fluent with extensive footnotes and explanations of some key concepts. However, Lau's intended readers are ordinary readers that who know no Chinese, so there is no need to give abundant notes as long as the ideas are clear.

\subsection{The Translating Purposes Determine Translating Strategies}

There are generally two kinds of translation strategies, either the translation adapts to the target language and culture or it sticks to the source language and culture. They are also called domestication and foreignization. Let us compare the differences of their translation strategies by the follow example.

吾日三醒吾身一为人谋而不忠乎?与朋友交而不信乎?传不习乎?

Legge: I daily examine myself on three points: whether, in transacting business for others, I may have been not 
faithful; whether, in intercourse with friends, I may have been not sincere; whether I may have not mastered and practiced the instructions of my teacher.

Waley: Every day I examine myself on these three points; in acting on behalf others, have I always been loyal to their interests? In intercourse with my friends, have I always been true to my word? Have I failed to respect the precepts that have been handed down to me?

Lau: Every day I examine myself on three counts. In what I have undertaken on another's behalf, have I failed to do my best? In my dealings with my friends have I failed to be trustworthy in what I say? Have I failed to practice repeatedly what has been passed on to me?

Legge's translation strictly follows the original sentence mode of three juxtaposed clauses. He paralleled three sentences with the same pattern: "whether......I may......" In order to represent the original language character, he sacrificed the fluency of the text. Waley and Lau's translation is more fluent in accordance with the English expression convention. Here, again, Legge's strategy, literally, is more of foreignization, while Waley and Lau's is more of domestication.

A translator's adoption of translation strategies is always related to his translating purpose. Concerning his identity as a missionary, Legge's translation purpose is obvious. As an enthusiastic British missionary who was sent to Hong Kong, China to spread Christianity, his major desire is that Confucius can be replaced by Jesus Christ. However, mainly because of his accompanied aim of invasion of Great Britain to China, his work was strongly resisted by Chinese Confucianism. Instead of opposition and violence, Legge tried a peaceful way by communicating and conciliating with Confucian thoughts. From his viewpoint, "Only thoroughly by mastering the Chinese classics and reviewing the whole thoughts that the Chinese ancestors established, upon which Chinese moral, social and political life rested and by translating the Chinese classics systemically can a qualified missionary in China fulfill his mission work and spread Christianity efficiently." (Zhu, 1994, p.119) With this attitude, Legge tried to keep the taste of the original as much as possible for the western readers. However, his effort remains mainly on language form. When it comes to the cultural terms, he tends to use domestication. Legge realized that the only way to approach the preach to them was to learn about what they believed and convince them that "God" had long existed in their literature.

Although Arthur Waley and D.C. Lau came from different country, their identity of scholar made their translating strategy be similar. Waley translated Lunyu for interest. D.C. Lau's purpose of translating clearly promoted the Chinese culture. Both of them wanted to introduce Chinese culture to Western. In their translations, they are generally more favored of domestication on and sentence structure, but when it comes to certain China specific cultural items, they usually applied foreignization

For example:

子曰:饱食终日, 无所用心, 难矣哉!不有博亦者乎?为之, 犹贤乎已.

Legge: The Master said, "Hard is it to deal with him, who will stuff himself with food the whole day, without applying his mind to anything good! Are there not gamesters and chess players? To be one of these would still be better than doing nothing at all."

Lau: The Master said, "The man whose belly is full all day and who does not put his mind to some use is sure to meet with difficulties. Are there not such things as Bo and Yi? Even playing these games is better than being idle.

While Yiis the game known as Weiqi later ages (better know in Western countries by its Japanese reading go), Bo is believed to have been a board game in which the moves of the pieces are decided by a throw of dice.

Here, for the two Chinese games"Bo"and"Yi", Legge used meaning translation, while Lau translated it literally with annotation. "Bo"and" Yi"are two items specific in the Chinese culture, they do not exist in western cultures. Lau applied foreignization to handle them in translation, they may be a little strange to the readers, but with the notes beneath, the readers will understand what they are. In this way, he introduced the two games to his western readers with intact information.

\section{Translation of Cultural Messages}

Translation is a forceful replacement of the original both linguistically and culturally. The Rendering of cultural messages in translation is as important, if not more, as the conversion of two languages, and it is usually the most difficult part, as the specific cultural identity of the translator has imposed him or her pre-existing values, beliefs and representations. As James Legge and Arthur Waley both were foreigners, their cultural identities were similar. We mainly compare James Legge and D.C.Lau' translations. 


\subsection{On Religious Culture}

Confucianism didn't start as a religion, but over the centuries, with its tremendous influence in shaping the moral, political and social life of the Chinese people, has been functioning as a religion. It affects values, laws, customs, rites and general behavior patterns of the nation and culture. In the past centuries, Confucianism has been used as a control mechanism, a way of achieving order, of delegating roles and responsibilities, which are exactly the roles that religion has played in the human history. Confucianism is a set of behavioral rules and moral standards which would bring order and harmony to the society and allow the society to function in an organized and systematic manner. More and more scholars reckoned Confucianism one of the three major religions in China, among which the other two are Taoism and Buddhism.

Just as religion is an important part of a culture, one's religious belief is an important part of one's cultural identity. From the life story of James Legge and D.C. Lau, it is clear that James Legge is from a culture where Christianity is the predominant religion; moreover, he is a Christian missionary himself. While D.C. Lau, as a Chinese scholar, is from a culture shaped by Confucianism, Taoism and Buddhism. This difference of religious belief certainly has influenced their choices in translation while dealing with the terms that carry heavy religious load. Taking their different translations of “神” in the Analects as an example.

祭如在, 祭神如神在.子曰:吾不与祭, 如不祭.

Legge: He sacrificed to the dead, as if they were present. He sacrificed to the spirits, as if the spirits were present. The Master said, "I consider my not being present at the sacrifice, as if I did not sacrifice."

Lau: "Sacrifice as if present" is taken to mean "sacrifice to the gods as if the gods were present." The Master, however, said, "Unless I enter into the spirit of a sacrifice, it is as if I did not sacrifice."

樊迟问知。子曰:务民之义, 敬鬼神而远之, 可谓知矣。

Legge: Fan Ch'ih asked what constituted wisdom. The Master said, "To give one's self earnestly to the duties due to men, and, while respecting spriritual beings, to keep aloof from them, may be called wisdom."

Lau: Fan Ch'ih asked about wisdom. The Master said, "To work for the things the ordinary people have a right to and to keep one's distance from the gods and spirits of the dead while showing them reverence can be called wisdom."

子不语:怪, 力, 乱, 神

Legge: The subjects on which the Master did not talk were extraordinary things, feats of strength, disorder, and spiritual beings.

Lau: The topics the Master did not speak of were prodigies, force, disorder and gods.

In all of the above examples, a common difference can be found in the translation of "Shen" or "Guishen". Legge translated it into "spirits" or "spiritual beings"; Lau translated it with "gods" or "spirits and gods".

The reason for his choice was related to his religious identity and his opinions on the relation between Confucianism and Christianity. Being a missionary in China, it had always been his intention to seek relative value of the truths contained in the Classics and those set forth in the Sacred Scriptures, so the preaches of God and Gospel will be easier for the Chinese people to accept. In his research, he believed that there were common values and truth between Confucianism and Christianity, and that the Chinese had the idea of God too. In his opinion, "Shen" in the Analects, is the word God's equivalent in Chinese "Di", which is a superior being to Shen. He pointed out if translating "God" to "Shin", what follows was to call the Chinese to worship Shin, which would be "to change the glory of God into a Lie". The translation of Shen was a serious issue, it involves the ultimate worship to God. Therefore, he translated "Shen" as "spirits" not "gods".

Different from Legge, D.C. Lau grew up and received the major part of his education in China. Christianity is not rooted in his religious background. To him, the word "god", especially when the initial letter is not capitalized, does not bear as much Christianity as it does to Legge. Leaving the religious influence of Christianity behind, "god" is literally equivalent to "Shen" in Chinese. Therefore, he rendered "Shen" to "god" in his translation.

\subsection{On Political Culture}

The art or science of government or ruling the people is a major part of the Confucian Analects. Confucius devoted most of his life in pursuing the realization of his political ideals. The early political thoughts of Confucianism had enormous influence in shaping and developing the feudal political system for the past two thousand years in the Chinese history. To translate Lunyu, the political culture is an undetectable aspect for 
consideration.

Between European and Chinese political philosophies and systems, there have always been tremendous and profound differences. The modern western political system was built on the basis of the Social Contract theory, which holds that authority should be generated out of agreements or covenants, and the essential view behind this is that all men are made by nature to be equals, therefore no one has a natural right to govern others, and therefore the only justified authority is the authority that is generated out of agreements or covenants.

The Social Contract theory implies an extremely strong and direct form of democracy. Therefore, the government is the representative of the general will of the people, its authority is given by the people, and its purpose is to serve the people. The influence of this idea can be found in the political systems of many today's western countries.

In China, however, where the feudal system had prevailed for over two thousand years, the concepts as freedom, democracy, and equality were completely alien. In this system, the emperor was the supreme power, whose ultimate authority was bestowed by heaven, and therefore unquestionable. The people were his servants, and were supposed to follow his rule. The Empire was organized under the will of the emperor, and its sole purpose was to guarantee the sovereign power of the royal family. Laws and policies were made not for the people, nor were the people involved in the enacting of them, but to keep people in order and under control. And the philosophy behind this political system was Confucianism.

This difference in the political culture between western and China has had its impact on James Legge and D.C. Lau in their translations. For example:

子日:为政以德，譬如北辰，居其所而众星共之.

Legge: The Master said, "He who exercises government by means of his virtue may be compared to the north polar star, which keeps its place and all the stars turn towards it.

Lau: The Master said, "The rule of virtue can be compared to the Pole Star which commands the homage of the multitude of stars simply by remaining in its place."

Legge translated “为政” with “exercises government", while Lau used "rule". There is a difference between the central concepts of the two words "government" or "govern" and "rule". "Govern" is usually related to ideas as "administer", "regulate", "public policy and affairs", etc; however "rule" is essentially "control", "command", "dominant", "power", "super authority", etc. "government" is associated with the western political system, representing the idea of democracy and general will of the people, with the purpose of serving the people and is supervised by the people. China didn't have a system equivalent to "government" in this sense until the modem ages. The over two thousand years practice of feudal empires was "ruling", not "governing". James Legge, due to his western background, primarily chose what they used to address the reign system to translate "Weizheng", but Lau, with his Chinese cultural background, tend to be more sensitive on this point, and used the word "rule", whose connotation is closer to the actual practice of sovereign in ancient China. Besides their different Rendering of the political organization, Legge and Lau's choices in addressing the person in authority "Jun", and their subordinates "Chen" are different too. For example:

定公问:君使臣，臣事君，如之何?

孔子对曰:君使臣以礼, 臣事君以忠。

Legge: The duke Ting asked how a prince should employ his ministers, and how ministers should serve their prince. Confucius replied, "A prince should employ his ministers according to the rules of propriety; ministers should serve their prince with faithfulness."

Lau: Duke Ting asked, "How should the ruler employ the services of his subjects? And how should a subject serve his ruler?" Confucius answered, "The ruler should employ the services of his subjects in accordance with the rites. A subject should serve his ruler by doing his utmost."

齐景公问政赞孔子。孔子对曰:君君，臣臣，父父，子子。

Legg: The duke of Ching, of Ch'I, asked Confucius about government. Confucius replied, "There is government, when the prince is prince, and the minister is minister; when the father is father, and the son is son."

Lau: Duke Ching of Ch'I asked Confucius about government. Confucius answered "Let the ruler be a ruler, the subject a subject, the father a father, the son a son."

In all the above example, Legge translated "Jun" as "prince", "Chen" as "minister"; Lau translated "Jun", as "ruler", and "Chen" as "subjects". Semantically, both of their translations are equivalent to the Chinese "Jun" 
and "Chen", but the cultural images they created in readers' minds are different. "Prince" reminds readers of the "king" and the European monarchy . "Minister" can be one who is authorized to perform religious functions or a state-appointed executive or administrative high officer. It is associated either with the Christian church, or the modern western government. While "ruler" and "subjects" are words that do not bear much cultural information other than their meanings. They are not associated with certain culture images. This is another demonstration of how James Legge's cultural identity as a Christian and European scholar affects his choices in translation.

\subsection{Key Term "Ren"}

Ren, which occurs hundreds times in The Analects is the fundamental virtue of Confucian teaching. Ren is the core concept in The Analects, playing a leading role in Confucius' ideological system. Confucius' focus on "Ren" suggests his general interest in the cultivation of moral character. This simple word possesses profound connotations. The definition of Ren has long been the focus of Confucianism.

$\mathrm{Zhu} \mathrm{Xi}$ : Ren is the principle of love and the virtue of the heart or the perfect virtue of the heart.

Qian Mu: Ren is the way of getting along with other people (Qian, 2002, p.6).

From those interpretations of the Chinese Confucius scholars', we can see Ren refers to an inner capacity of all human beings to love people and to get along with people. The difficulty lies in the fact that on different occasions Confucius often gives different explanations for it. So Ren is indeed a difficult concept to translate, for it contains profound philosophical meanings, and different translators have their different understanding of this term and all find good justification for their various Renderings.

孝弟也者, 其为仁之本与

Legge: Filial piety and fraternal submission! - are they not the root of all benevolent actions?

Waley: And surely proper behavior towards parents and elder brothers is the trunk of Goodness?

D.C.Lau: Being good as a son and obedient as a young man is, perhaps, the root of a man's character.

克已复礼, 为仁

Legge: To subdue one's self and to propriety is perfect virtue.

Waley: He who can himself submit to ritual is Good

D.C.Lau: To return to the observance of the rites through overcoming the self constitutes benevolence.

Legge selected "benevolent actions", "true virtue", "the good", "the virtues proper to humanity" to render this term. Legge selected "virtue", which means "moral goodness or excellence" is relatively close to the original meaning. Waley selected "the good", "goodness" to render this term. His Rendition of Ren enlarges the original meaning, and ignores the connection Ren with man. In the D. C. Lau interprets “仁” into “人” and render Ren into "the man" which show them tendency of collecting this term to human relation between each other. D. C. Lau Render Ren into benevolence, which means "willing to help and be generous towards people." which is relatively close to the original meaning. The differences come from their cultural identity, as this concept does not exist in the West.

\section{Conclusion}

From the above discussion, it is clear that a translator can not break away from his cultural identity. By comparing examples from their translated versions of Lunyu on various aspects, including application of translation strategies, dealing of religious and political cultural messages and key terms, we have reason to believe that, the various elements that construct a translator's cultural identity are and James Legge's cultural was more typical, always playing some sort of role in his translation, either the translator being aware of it or not.

Because of their different identity, translating purposes, and target readers, etc, they applied domestication and foreignization to different aspects. In dealing with cultural messages, the tremendous distinction between the western and Chinese religion and political ideas also affected their choices in translation.

In a word, translators' identity influences their translations, when you translate articles or read translations, you should pay more attention to it.

\section{References}

Bates, D. G., \& Plog, F. (1990). Cultural anthropology. New York McGraw-Hill, p.28.

Hamers, J. F., \& Blanc, M. H. (1989). Bilinguality and bilingualism. Cambridge University Press, p.116. 
Legge, J. (1971). The Great Learning \& the Doctrine of the Mean. Dover Publications, p.19.

Nida, E. (1969). The theory and practice in translation. Leidea: E. J. Brill, p.176.

Nord, C. (2001). Translating as a Purposeful Activity. Shanghai: Foreign Language Education Press, p.89.

Qian, M. (2002). The New Interpretation of Analects of Confucius. Beijing: SDX Joint Publishing Company, p.6.

Ride, L. (1960). Biographical Notes. The Chinese Classics Vol I. Hong Kong: Hong Kong University Press, p.58.

Zhu, X. (1994). The Four Books. Beijing: Cathay Bookshop, p.119.

\section{Copyrights}

Copyright for this article is retained by the author(s), with first publication rights granted to the journal.

This is an open-access article distributed under the terms and conditions of the Creative Commons Attribution license (http://creativecommons.org/licenses/by/3.0/). 